ELWIRA WARDA - LUBLIN

\title{
SKRYPTORIUM PODSTAWĄ ROZWOJU BIBLIOTEK
}

\begin{abstract}
Kiedy w miejscu tym zasiądą ci, którzy przepisują wyrocznie świętego prawa, niech wystrzegają się wszelkich płochych słów, w obawie, aby ich ręce również nie zabłąkały się wśród błahostek: niech się starają przepisywać poprawnie książki, które im powierzono, i niechaj ich pióro biegnie prostą drogą ${ }^{1}$.
\end{abstract}

Twórcą właściwego życia zakonnego, tzn. prowadzonego według ściśle określonej reguły jest św. Pachomiusz, który w IV wieku założył claustrum otoczone ogrodzeniem wspólnoty domków dookoła kościoła. Jednym z wielkich przedstawicieli mniszego życia był św. Bazyli Wielki (330-379), który założył klasztory w Poncie i Kapadocji oraz ułożył dla nich regułę, która rozpowszechniła się na całym Wschodzie. Życie zakonne przedostało się do Europy, w której najwybitniejszą postacią średniowiecznego monastycyzmu był Benedykt z Nursji, założyciel klasztoru na wzgórzu Monte Cassino. Jego maksyma Ora et labora właściwie streszcza całą regułę benedyktyńską. Wokół pracy i modlitwy koncentruje się życie wspólnoty, a dzięki pracy w klasztornych skryptoriach benedyktyni rozpowszechniają skarby kultury europejskiej.

\section{Skryptorium}

Przy każdym dużym klasztorze i przy każdej siedzibie biskupa istniało skryptorium. Skryptorium to sala, gdzie mnisi przepisywali manuskrypty (z lac. liber manu scriptus $=k$ siążka napisana ręcznie). $\mathrm{Z}$ biegiem czasu praca ta stopniowo stała się ich specjalnością. W ciagu dnia kopista mógł przepisać od 3 do 6 kart formatu in quarto, w ciagu życia nawet czterdzieści książek.

\footnotetext{
${ }^{1}$ Słowa te zostały wypisane u wejścia do skryptorium w opactwie Saint-Martin w Tours.
} 
Jako skryptorium zazwyczaj służyła osobna sala wspólna dla wszystkich pisarzy, zwłaszcza w klasztorach benedyktyńskich lub kilka mniejszych indywidualnych cel $-u$ cystersów i kartuzów. Powstałe w skryptoriach rękopisy - zarówno dokumenty, jak i kodeksy ${ }^{2}$ - przetrwały w archiwach i bibliotekach. Cystersi, tak jak i benedyktyni, posiadali wysoko rozwinięte warsztaty pisarskie. Natomiast organizacja kartuzów różniła się od innych organizacji monastycznych posiadaniem grupy eremów (kartuzji). Każdy mnich mieszkał osobno, a klasztor pierwotnie składał się z oddzielnych chatek. Życie pustelnika w jego celi było tak zorganizowane, aby umożliwić kontemplację - podstawowy cel kartuzów. Mnichów zachęcano do pracy fizycznej, a szczególnie zalecanym zajęciem, oprócz medytacji, czytania oraz modlitwy, było przepisywanie ksiąg. Każda cela kartuzji była oddzielnym skryptorium zaopatrzonym w pergamin, pióra, kałamarz i linijkę.

Czasem w klasztorach benedyktyńskich skryptorium połączone było z biblioteką ${ }^{3}$. Podstawowym sprzętem w tym pomieszczeniu był stół lub pulpit, $\mathrm{z}$ pochyłym blatem, służącym jako podstawa do rozłożenia książki przy czytaniu lub pisaniu. Nad nią lub pod nią znajdowała się półka, na której ustawiano książki, które często przytwierdzano łańcuchami, tzw. libri catenati. ${ }^{4}$ Pulpity przyjęły się w późniejszym średniowieczu i były przystosowane do siedzenia lub stania, jedno- lub dwustronne, proste lub ozdobne. Oprócz pulpitu w skryptorium znajdowała się szafa z materiałami pisarskimi i wzorami do kopiowania. Do pracy w skryptorium zakonników wyznaczał opat, a liczba kopistów zależała od zamożności klasztoru. Kopiści dzielili się na wykwalifikowanych kaligrafów (antiquarii = antykwariusz) oraz nowicjuszy (scriptore $=$ skryptor). Skryptor pracował około 6 godzin, zwykle przy świetle dziennym. Dni oraz pory dnia przeznaczone na przepisywanie ksiag określały statuty poszczególnych zakonów. Na utrzymanie skryptorium i biblioteki przeznaczano część dochodów klasztornych. Nadzór nad skryptorium sprawował bibliotekarz lub zakonnik wyznaczony przez opata.

Zapisywanie ksiąg składało się z następujących czynności: po utworzeniu składek, zaznaczano w nich przez nakłucie rozmiary kolumny pisma, decydowano czy ma być jedna kolumna czy dwie, następnie stronice liniowano delikatnym, tępym rysikiem, od wieku XII najczęściej sporządzanym z ołowiu. W obrębie tych linii pisarz wypełniał karty obustronnie tekstem, zostawiając wolne miejsca dla ozdobnych inicjałów i tytułów rozdziałów. Tekst pisano czarnym atramentem, litery zaś i wyrazy, które chciano wyróżnić, pisano albo podkreślano lub przekreślano glinką czerwoną, czyli rubryką, a później minią, tj. czerwienią ołowianą.

${ }^{2}$ Kodeks (łac. caudex, codex = pień drzewa, kloc) - forma książki. W średniowieczu kodeks był jedyną formą książki z kartami pergaminowymi, później papierowymi.

${ }^{3}$ Takie rozwiązanie było w klasztorach irlandzkich.

${ }^{4}$ Libri catenati (łac. księgi łańcuchowe) - księgi przymocowane do szafy (armarium) lub w późnym średniowieczu do pulpitu za pomocą łańcucha. Jeden koniec łańcucha przytwierdzony był do żelaznego kółka u dołu albo u góry tylnej okładziny książki, drugi nawleczony na poziomy pręt przy szafie lub blacie pulpitu. Zwyczaj ten, stosowany w średniowieczu, panował jeszcze w XVI i XVII w. Miał na celu nie tylko zapobieganie kradzieży, ale też chronił przed przestawianiem książek przez użytkowników. 
Pracę tę, zwaną rubrykowaniem ${ }^{5}$, wykonywał początkowo sam pisarz lub kopista, później (od XIII w.) specjalny rubrykator czy miniator. Gdy rękopis chciano szczególnie upiększyć, zaopatrywano go $\mathrm{w}$ inicjały ${ }^{6} \mathrm{i}$ bordiury malowane, nieraz dodawano kolorowe i złocone obrazki, tzw. miniatury. Taką księgę oprawiano w rozmaity sposób zależnie od przeznaczenia księgi.

Arkusz, czyli folium, składano na dwie albo na cztery karty: folia wkładano jedno w drugie, najczęściej cztery folia z ośmioma kartkami o dwóch stronach, tworząc w ten sposób składkę zwaną quaternion. Kopiści siadali na ławie, stopy opierali na podnóżku, pergamin umieszczali na pulpicie albo na kolanach. Obok leżał rękopis, który mieli skopiować, ale najczęściej pisali pod dyktando lektora. Przed zabraniem się do pracy wypróbowywali pióra kreśląc na marginesie parę liter alfabetu albo pierwszy werset psalmu. Czasem, nie mogąc wymieniać między sobą swoich uwag, wypisywali na marginesie jakieś własne refleksje: „- zimno dzisiaj - lampa źle się pali - dziś nie czuję się dobrze - czas zabrać się do pracy - już pora na śniadanie”. Praca kopisty była ciężka, szczególnie w zimie. Kończąc przepisywanie kopista poleca swą duszę modlitwom tego, kto będzie czytał ten rękopis.

Kopista rzadko pracował sam. W wielkich skryptoriach trudziły się nad kopią zespoły ludzi. Zazwyczaj na skopiowanie rękopisu średniej objętości trzeba było dwóch do trzech miesięcy. W ukończonym rękopisie należało poprawić błędy, których nigdy nie brakowało. Dzieło trafiało do rąk korektora, który porównywał je z oryginałem. Funkcje korektora pełnili najbardziej wykształceni członkowie konwentu i byli to najczęściej opaci.

\section{Materiał piśmienny}

Podstawowym materiałem piśmiennym w epoce średniowiecza był perga$\min ^{7}$, który wyrabiano ze wszystkich rodzajów skór, ale najczęściej do jego produkcji używano skór cielęcych, owczych oraz kozich. Skórę przez kilka dni moczono w wodzie wapiennej, następnie usuwano sierść i ponownie moczono, gar-

${ }^{5}$ Rubryka (łac. rubrica terra $=$ czerwona ziemia) - w rękopisie zdanie, wyraz lub litera wykonana czerwoną (rzadziej innego koloru) farbą w odróżnieniu od całości tekstu pisanego na czarno. W ten sposób uwydatniano zwłaszcza tytuliki, incipity, kolofony itd. Często też stosowano przekreślanie liter czerwoną (czasem inną) farbą, mające na celu ożywienie jednostajnego wyglądu zapisanych kart.

Nazwa pochodzi od rubrum - tlenku żelaza, z którego we wczesnym średniowieczu wyrabiano czerwoną farbę lub inkaust.

${ }^{6}$ Inicjał - ozdobna pierwsza litera tekstu w rysie lub druku, ujęta w określone pole (kwadrat, owal) lub zamykająca w sobie ilustrację i ornament. Rozmiary inicjałów są bardzo różne: od niewiele większych od pisma tekstu do zajmujących całą stronę. Już od V wieku inicjały występują w rękopisach. Belki liter początkowo wypełnia ornament geometryczny, później tworzą je ryby lub pta$\mathrm{ki}$, plecionka oraz wić roślinna (X w.). W gotyku pojawiają się sceny figuralne.

${ }^{7}$ Nazwa pergamin (membrana pargamenea) ma pewien związek z miastem Pergamon w Azji Mniejszej, słynnym swą bogatą biblioteką, centrum życia umysłowego i kulturalnego w epoce hellenistycznej. (Władysław Semkowicz, Paleografia łacińska, Universitas, Kraków 2007, s. 51). 
bowano substancją roślinną i suszono na drewnianych ramach. Po tych zabiegach skórę skrobano ciężkim nożem i pocierano pumeksem. W okresie późniejszym skórę blichowano, czyli wybielano posypując warstwą sproszkowanej kredy. Dzięki temu stawała się ona miękka, elastyczna i biała. Pergamin był materiałem piśmiennym trwalszym od papirusu, a do pisania i iluminowania nadawały się obie strony. Pergamin był łatwiejszy do składania i podczas zszywania nie łamał się.

Początkowo wyrobem pergaminu zajmowały się klasztory, natomiast od XII wieku zawodowi pergaminiści (pergaminarii). Rozróżniano dwa gatunki pergaminu: południowy (włoski, charta italica) i północny (niemiecki, charta theutoni$k a$ ). Pergamin południowy był z cienkiej, dokładnie wyprawionej skóry, wygładzonej tylko $\mathrm{z}$ jednej strony, natomiast druga strona pozostawała chropowata i żółta. Ten gatunek pergaminu wyrabiano we Włoszech, w Hiszpanii oraz w południowej Francji. Pergamin północny, pochodzący z Francji, Niemiec, Polski oraz Węgier, był grubszy od południowego. Wyprawiano go z obu stron jednakowo. We wczesnym średniowieczu do wyjątkowo cennych ksiag używano pergaminu barwionego purpura, na którym pisano farbą złotą lub srebrną.

Ważną zaletą pergaminu była możliwość usuwania z niego pisma i ponownego wpisania nowego tekstu. W okresie średniowiecza dosyć często stosowano takie rozwiązanie z powodu wysokiej ceny materiału piśmienniczego. Inną zaletą pergaminu była ogólna dostępność materiału, który potrzebny był do jego wykonania.

Jeśli rękopis był ukończony pracę nad nim przejmował malarz. Zdobił inicjały, ujmował stronice $\mathrm{w}$ ramki, malował pozostawione dla niego strony według własnego smaku albo też w stylu szkoły, w której się wykształcił.

\section{Przybory do pisania}

\section{a) pióra}

Początkowo do pisania używano trzciny, a od około $\mathrm{V}$ wieku zaczęto pisać piórami ptaków, najczęściej gęsimi. Były one specjalnie przygotowane, czyli ścięte i rozszczepione na końcu. Średniowiecznego skrybę kopiującego tekst zazwyczaj każdy wyobraża sobie z gęsim piórem w ręku. Tak było rzeczywiście. W starożytności do pisania na papirusie używana była rozszczepiona trzcina (łac. calamus), a wystrzępiona służyła za pędzel. W VI wieku została zastapiona przez pióro i pędzel z włosia zwierzęcego. Przybory te były bardziej elastyczne i dzięki temu lepiej nadawały się do pisania na pergaminie, materiale twardszym niż papirus. Przybory do pisania skrybowie przygotowywali sami, a najbardziej do tego nadawały się pióra od pierwszej do piątej zewnętrznej lotki ze skrzydła gęsi lub łabędzia. Dla praworęcznego skryby najwygodniejsze było pióro naturalnie lekko wygięte w prawo, czyli pochodzące $\mathrm{z}$ lewego skrzydła ptasiego. Ilustracje średniowieczne pokazują skrybów jedynie z białą, wygiętą dudką, a nie z całym piórem. Pióra świeże od razu nie nadawały się do pisania, gdyż są zbyt giętkie. Potrzebują one utwardzenia i trzeba je pozostawić do wyschnięcia na kilka miesięcy 
albo zahartować przez ogrzewanie lub moczenie w wodzie i nagłe zanurzanie w gorącym piasku. Po zeskrobaniu cienkiej zewnętrznej skórki pozostawała niemal przezroczysta twarda tubka, której końcówkę z obu stron ścinano ostrym nożem, następnie centralnie rozcinano końcówkę pióra otrzymując kwadratowe zakończenie.

Średniowieczny skryba potrafił szybko przygotowywać pióra, gdyż w ciagu dnia pracy, pisanie wymagało od niego mniej więcej sześćdziesięciokrotnego ostrzenia pióra. Skryba najczęściej miał od 60 do 100 zapasowych gotowych piór. Najlepiej pisało się piórem trzymanym pionowo do kartki, a pisząc skryba poruszał całą ręką. Początkowo pochylał się nad pulpitem położonym na kolanach, a u schyłku średniowiecza siedział przed wygodniejszym ze względu na sposób trzymania pióra, stromo pochylonym blatem. Od XVI wieku pisano już na płaskim stole.

\section{b) atramenty}

Atrament trzymano w kałamarzach zrobionych ze zwierzęcych rogów. Kopiści niekiedy przedstawiani byli z rogami w rękach, ale zazwyczaj obie ich ręce są zajęte przez nóż i pióro. Ewangeliści przedstawiani na miniaturach w karolińskich ewangeliarzach atrament mają często poza pulpitem, na osobnych stojakach. $\mathrm{Na}$ obrazach późnośredniowiecznych rogi $\mathrm{z}$ atramentem najczęściej wkładano w metalowe obręcze przytwierdzone do prawej krawędzi blatu. Istnieją przykłady wkładania ich w otwory w pulpicie tak, że od spodu blatu widać ich zakończenia.

Nazwa inkaust ( $\mathrm{z}$ łac. encaustum $=$ wypalony) wywodzi się z tego, że zawarte w atramencie kwasy taninowy oraz galusowy i proces utleniania jego składników powoduja, iż wżera się w powierzchnię pergaminu. Podstawą średniowiecznych atramentów był roztwór garbników zawartych w galasie i gumie arabskiej, zabarwiony przez dodanie sadzy lub soli żelaza. Atrament (od łac. atramentum $=$ czernidło) wykorzystywano nie tylko do pisania, ale również do malowania i liniowania. Owczesne atramenty były gęstsze i bardziej lepkie niż produkowane obecnie. Istniały dwa rodzaje atramentu: weglowy stosowany do wieku XII produkowany $\mathrm{z}$ węgla drzewnego, brunatnego lub sadzy zmieszanego z gumą i galasowy, który przygotowywano z roztworu kwasów taninowych i soli żelaza. Był on bardziej przezroczysty i błyszczący, lepiej wsiąkał w pergamin i był trudniejszy do starcia od atramentu węglowego.

Podstawowym składnikiem atramentu galasowego były galasy lub dębianki, czyli kuliste narośle na liściach lub łodygach roślin, szczególnie dębu, które powstały wskutek gojenia się nakłutej tkanki i rozwoju wewnątrz larw ze złożonych jaj przez owady, głównie galasówki. Galas miażdżono i moczono w deszczówce, w winie albo w occie, przy ogniu lub na słońcu. Dzięki temu procesowi otrzymywano roztwór potrzebny przy produkcji atramentu. Drugim składnikiem była sól żelaza, tzw. witriol, wydobywana z pokładów żelaza w glebie przez odparowywanie wody. Dwa składniki mieszano i w wyniku reakcji chemicznej płyn osiagał powoli barwę od brązu do czerni. Na kartach manuskryptu inkaust ciemniał nawet 
jeszcze bardziej, lecz czasem też blaknął do koloru czerwonobrązowego lub nawet żółtego. Niekiedy do produkcji atramentu używano soli miedzi, która z czasem zmieniała barwę na szarozieloną. Taki atrament zagęszczano dodając gumę arabska, czyli wyschnięty sok drzewa akacjowego.

Atrament czerwony ${ }^{8}$ był następnym kolorem - po czarnym - często używanym. W manuskryptach pojawił się już w V wieku i używany był do wieku XV, natomiast atramenty niebieskie i zielone występowały rzadziej.

Czasem na kartach rękopisów można zauważyć większą koncentrację atramentu przy dolnych krawędziach liter z powodu pisania na pochyłych pulpitach. Przed rozpoczęciem przepisywania manuskryptu skryptor pergamin przecierał pumeksem i kredą wygładzał jego powierzchnię, aby pozbyć się ewentualnych tłustych plam, które mogły pojawić się podczas zaginania arkuszy. W taki sposób starano się zapobiegać rozlewaniu się atramentu. W czasie pisania $\mathrm{w}$ lewej ręce kopista trzymał nóż, który służył mu do ostrzenia piór oraz poprawiania błędów przed wyschnięciem atramentu, a także do przytrzymywania sprężystej powierzchni pergaminu. Przytrzymywanie kartki palcem było nieporęczne, a dodatkowo mogło powodować zabrudzenia.

We wczesnym średniowieczu skrybowie i iluminatorzy sami przygotowywali pigmenty, a około roku 1200 najczęściej nabywali potrzebne składniki w gotowej postaci od pośredników lub aptekarzy.

\section{Zdobienie manuskryptów}

\section{a) miniatury, iluminacje}

Ilustracje ksiąg liturgicznych, przede wszystkim ewangeliarzy przepisywanych ręcznie w skryptoriach klasztorów, ułatwiały ludziom nie umiejącym czytać zrozumienie dzieła boskiego. Ta tradycja ewangelizacji przez sztukę $\mathrm{w}$ epoce średniowiecza jako Biblia pauperum objaśniała prawdy wiary i wydarzenia z Ewangelii.

Miniatury malowane farbami kryjącymi zdobiły przede wszystkim księgi o treści religijnej. Natomiast w księgach świeckich przeważały ilustracje podmalowywane farbami wodnymi. Najbardziej reprezentacyjne rodzaje rękopisów iluminowanych to: codex aureus $^{9}$ (pisany i zdobiony złotem), codex purpureus (o

\footnotetext{
${ }^{8}$ Atrament czerwony (rubrum) znany był $\mathrm{w}$ trzech odmianach: purpura preparowana $\mathrm{z}$ krwi pewnego gatunku ślimaka (tzw. sacrum incaustum), cynober produkowany z mieszaniny rtęci i siarki oraz minia (minium) sporządzona $\mathrm{z}$ bieli ołowianej. W XV wieku produkowano czerwony inkaust $\mathrm{z}$ barwnego wyciagu z drewna brazilium sprowadzanego z Cejlonu. Wszystkich odmian czerwonego inkaustu używano do pisania inicjałów, tytułów i paragrafów, liniowania pod zapis muzyczny itp. w celu uwydatnienia danego fragmentu tekstu. Pisarze islamu prócz inkaustu czerwonego (mieszanina cynobru z sokiem granatu) używali inkaustu złotego (sproszkowane złoto, sok cytryny, woda, szafran i guma arabska), niebieskiego (lapis lazuli) i białego.

${ }^{9} \mathrm{~W}$ polskich zbiorach kodeksami złotymi są: Ewangeliarz gnieźnieński, Ewangeliarz pułtuski. Teksty pisane złotem na purpurze zawiera Sakramentarz tyniecki i Missale Plenarium.
} 
kartach malowanych purpura) i codex argenteus (wykonany przy użyciu srebra). Głównymi typami iluminacji są: inicjały ornamentalne i obrazkowe, ilustracje tekstowe (często całostronicowe) i obramienia dekoracyjne (floratury ${ }^{10}$, bordiury ${ }^{11}$, często wzbogacane motywem drôlerie ${ }^{12)}$. Niekiedy stosowano również iluminacje dedykacyjne, wskazujące na osobę fundatora księgi. Wspaniałym początkiem iluminacji ${ }^{13} \mathrm{w}$ kulturze zachodniego chrześcijaństwa były miniatury $\mathrm{w}$ irlandzkich ewangeliarzach z VII wieku wykorzystujące bujną ornamentykę germańsko-irlandzko-celtycka.

Podczas panowania dynastii Karolingów, którzy świadomie nawiązywali do rzymskiego antyku i pragnęli, by ich imperium było kontynuacją imperium Romanum, iluminatorstwo rozwijało się szybciej, kopiując formy późnego antyku. W okresie tym powstawały prężne ośrodki iluminatorskie na przykład na wyspie Reichenau na Jeziorze Bodeńskim. Stąd wychodzą okazałe iluminacje rękopisów cesarzy ottońskich, w których postacie namalowane były na połyskującym złotym tle przekształcają formy antyczne w pełną wyrazu monumentalną sztukę.

Iluminatorstwo rozwijało się stylistycznie w okresie romańskim, gotyckim i renesansowym. Iluminacje dostarczały wielokrotnie wzorów dla malowideł ściennych, tablicowych i witraży. Sztuka iluminatorstwa zaczęła podupadać wraz z pojawieniem się książki drukowanej, w której zadanie ilustracji przejmują drzeworyty. Wyjątkowo we Włoszech iluminacja zachowała się także po wynalezieniu książki drukowanej, do wieku XVI.

W II połowie XV wieku była skutecznie wspierana przez dobrze płacących zleceniodawców, takich jak papież, król Węgier Maciej Korwin, Medyceusze i d'Estowie. We Florencji iluminatorami byli m.in. Fra Angelico i Sandro Botticelli. Mistrzowskimi dziełami florenckiej iluminacji bez wątpienia są Godzinki Wawrzyńca de Medici (Biblioteca Laurenziana, Ms. Ashburnham, Florencja). Najsłynniejsze ośrodki iluminatorstwa znajdowały w Bizancjum, Irlandii, Francji, Niemczech, Włoszech oraz w Hiszpanii.

${ }^{10}$ Floratura (łac. flos $\left.=k w i a t\right)$ - rozwinięta dekoracja roślinna wypełniająca jeden lub kilka marginesów zdobionej karty. Stanowi etap pośredni w rozwoju roślinnej dekoracji marginalnej między wieżą, wyrastającą najczęściej z inicjału, a późnogotycką zamkniętą w obramienie bordiurą. Roślinność floratury często wzbogacają liczne elementy drolerii, przejęte ze świata fauny, legendy, anegdoty i groteski, jak również motywy heraldyczne. W polskim malarstwie książkowym floratura występuje od lat 70. XIV w. (Psałterz floriański). Była stosowana w zdobnictwie przez cały wiek XV.

${ }^{11}$ Bordiura (fr. bordure = obramowanie) $-\mathrm{w}$ książce rękopiśmiennej lub drukowanej zamknięta ramowo dekoracja wypełniająca wszystkie marginesy zdobionej karty. Bordiura może mieć charakter przedstawieniowy lub ornamentalny, może również zawierać sceny figuralne. Forma obramienia powtarzać może kształt otaczanego obiektu (np. rama kwadratu czy prostokąta zamknięta równoległymi liniami), może mieć także zupełnie odmienny kształt (np. kwadratowe pole w kolistym obramieniu). W iluminatorstwie przedromańskim i romańskim bordiura posiadała charakter regularnego obramienia przeważnie nie związanego z miniaturą lub inicjałem.

${ }^{12}$ czyli zdobienia małymi scenkami figuralnymi lub zwierzęcymi, odznaczającymi się humorem, fantazją, groteskową deformacją i zaskakującymi zestawieniami elementów.

${ }^{13}$ Iluminacja (łac. illuminare $=$ rozświetlać) - pierwotnie oznaczała zdobienie złotem karty książki. Iluminację malowano farbami kryjącymi (woskowymi lub temperą) albo wodnymi, rysowano piórem, srebrnym sztyftem lub cienkim pędzelkiem. 


\section{b) oprawy}

Ostatnim etapem w produkcji książki średniowiecznej było zebranie poszczególnych składek tekstu i wykonanie oprawy. Początkowo skryptorzy sami zajmowali się oprawianiem, często zawijając je w miękki pergamin i zawiązując rzemykiem. W epoce całego średniowiecza do ochrony dużego zazwyczaj kodeksu, konieczna była odpowiednio trwała i mocna oprawa, której okładziny tworzyły deski dębowe i bukowe, pokryte skórą. Stąd wywodzi się znane powiedzenie: Przeczytać ksiażkę od deski do deski. Dla zabezpieczenia opraw skórzanych nakładano ozdobne metalowe narożniki i guzy. Blok książki spinano klamrą, aby księga się nie rozwierała.

Ze względu na używane materiały i techniki introligatorskie można wyróżnić kilka typów opraw średniowiecznych:

- oprawy złotnicze lub ołtarzowe - oprawy takie używane były, zwłaszcza w okresie wczesnego i dojrzałego średniowiecza, do oprawiania najbardziej reprezentacyjnych ksiag. Jako materiał do tego rodzaju opraw stosowano kość słoniową, wykorzystywano kamienie szlachetne, srebro oraz złoto. Od wieku XV zwyczaj drogocennego oprawiania przestał być powszechny.

- oprawy mnisze lub klasztorne - stosowane były do manuskryptów, później do inkunabułów ${ }^{14}$. Oprawa była skromna i zazwyczaj składała się z dość grubych desek, obciagnniętych skórą i to tylko na części okładzin i na grzbiecie księgi. Ozdoby opraw były bardzo skromne. Najczęściej w powierzchnię skóry wtłaczano krzyżujące się przekątnie linie lub ramki. Natomiast grzbiety opraw nie były zdobione.

- oprawa sakwowa - była powszechna od wieku XIV do XVI. Materiał powlekający oprawę (mogła to być miękka skóra, jedwab lub aksamit) przedłużał się u dolnego brzegu książki w duży płat luźno zwisający. W razie potrzeby można było płat sfałdować, związać w węzeł i przytroczyć księgę do pasa. Oprawy sakowe w Polsce się nie zachowały. Dowodem na to, że były one rozpowszechnione są zachowane miniatury i rzeźby $\mathrm{z}$ wieku XV, na których święci trzymają w rękach takie księgi.

- oprawa płaszczowa - podobna była do oprawy sakwowej. Oprawiona już księga otrzymywała dodatkowe pokrycie z miękkiej skóry, aksamitu lub jedwabiu, znacznie obszerniejszego niż powierzchnia książki. Szeroki płat materiału zwisał poza brzegi i w razie potrzeby otulał całą książkę jak płaszczem. Taka książka zamykała się zazwyczaj na rzemienne klamry przeciagane przez otwór w pokryciu płaszczowym, które spinały mocno obie okładziny.

${ }^{14}$ Inkunabuł (łac. incunabula $=$ powijaki) - umowne określenie pierwszych druków. Za początek powstawania inkunabułów przyjęto datę ukazania się pierwszego inkunabułu: Biblii 42-wierszowej wydanej przez Johannesa Gutenberga w roku 1455. W wielu krajach przyjęto zasadę, że przełom wieków XV i XVI, ściślej mówiąc 31 grudnia roku 1500, stanowi taką umowną granicę. Jednak nie we wszystkich krajach wybrano taką cezurę. Tam, gdzie sztuka drukarska dotarła późno, np. w Skandynawii, tam rodziły się tendencje do przesunięcia daty inkunabułu na rok 1525 . 


\section{Szkoły kaligraficzne}

W skryptoriach klasztornych powstawały szkoły kaligraficzne wytwarzające swoiste typy i formy pisma. Największe znaczenie miały one we wczesnym średniowieczu, gdy nie rozpowszechniona jeszcze znajomość pisma oraz rzadkie kontakty między poszczególnymi ośrodkami produkującymi książki sprzyjały rozwijaniu się w nich specyficznych form i zwyczajów pisarskich. W miarę coraz szerszego przyjmowania się powszechnych typów pisma, takich jak minuskuła karolińska oraz w miarę rozpowszechniania się znajomości sztuki pisarskiej, szkoły kaligraficzne stopniowo zatraciły swój charakter i znaczenie. Najdawniejsze szkoły powstały na terenie Włoch i Francji. Jedna z nich w Vivarium około roku 540 założył Kasjodor, lecz niestety cały jej pisarski dorobek uległ rozproszeniu. W VIII wieku rozwinęła się szkoła kaligraficzna na Monte Cassino, gdzie powstało pismo benewenckie oparte na rzymskiej kursywie. Przez długi czas południowe Włochy były pod jej wpływem. Po okresie upadku - przyczyną było zburzenie klasztoru przez Saracenów w roku 883 - doszła ponownie do rozkwitu w wieku XI. Jej wpływy były tym silniejsze, że klasztor Monte Cassino posiadał liczne filie nie tylko we Włoszech, ale nawet w Dalmacji.

\section{Biblioteki średniowieczne}

Ważną część kościelnych skarbców stanowiły książki i dlatego przechowywano je z tak wielką troskliwością. Obok skryptorium mieścił się lokal przeznaczony na bibliotekę. Książki trzymano w skrzyniach, a rzadziej w szafach zamykanych na klucz, który powierzano bibliotekarzowi.

Klasztory posiadające większą ilość książek (od kilkuset do tysiąca) musiały mieć więcej miejsca na ich przechowywanie, jakkolwiek nie posiadały od razu oddzielnych pomieszczeń. Przeważnie w klasztorach przechowywano książki w niszach krużganków (chiostra). Dopiero u schyłku średniowiecza w większych klasztorach biblioteką było pomieszczenie, przeważnie długie, a wąskie, z obu stron dobrze oświetlone. Księgi, o ile nie były złożone w skrzyniach lub przechowywane w oddzielnych pudłach (capsae), stały w szafach (przeważnie wpuszczonych w ścianę), stąd nazwa łacińska biblioteki armarium = szafa ${ }^{15}$. Gdzie było ich niewiele, wystarczała szafa zaopatrzona w półki, na których stały lub leżały kodeksy licem kart na zewnątrz, a nie jak obecnie grzbietem. W późniejszym średniowieczu w bibliotekach zaczęto stosować system pultowy. Pulty były jedno- lub dwustronne, wyższe do czytania w pozycji stojącej (np. w bibliotece uniwersyteckiej w Lejdzie), a niższe z ławami do siedzenia. Ksiegi leżały na pultach, przymocowane do nich łańcuchami.

${ }^{15}$ Armarium - w starożytności i w średniowieczu szafa na książki z zamykanymi drzwiami. W początkowym okresie książki leżały na półkach, później stawiano je grzbietami do ściany. Opiekun biblioteki, armarius (librarius) czuwał nad porządkiem i czystością książek oraz nad opracowaniem katalogów, które zazwyczaj były listami inwentaryzacyjnymi. Do obowiązków armariusa należało także wypożyczanie ksiąg. 


\section{Polskie skryptoria klasztorne}

Najwcześniejsze dane o działalności skryptoriów klasztornych w Polsce pochodzą z wieku XIII. Większe znaczenie zdobyły skryptoria klasztorów w Krakowie, Tyńcu, na Łysej Górze, w Sieciechowie, Lubiniu, Koprzywnicy, Lądzie, Paradyżu, Sulejowie oraz na Śląsku - w Lubiążu, Henrykowie, Legnicy, Żaganiu i Wrocławiu. Najstarszym z nich było skryptorium założone na Łysej Górze w pierwszej połowie XII wieku w klasztorze benedyktyńskim Św. Krzyża. Spustoszenia spowodowane przez najazdy tatarskie w XIII wieku, podczas których został zniszczony dobytek klasztoru, nie pozwalają na ocenę działalności skryptorium w pierwszym okresie. Nie wiadomo również, w jakim stopniu przyczyniło się do jego rozwoju sprowadzenie zakonników z Monte Cassino przez Bolesława Wstydliwego. Najstarsze znane kodeksy biblioteki łysogórskiej (około 18 woluminów) pochodzą z XIV wieku i nie ma żadnych podstaw, by widzieć w nich produkty klasztornego skryptorium. Pierwszym wyraźnym śladem pisarskiej działalności klasztoru jest wiadomość, że do XVIII wieku biblioteka przechowywała autograf thumaczenia kroniki Widukinda, dokonanego przez opata łysogórskiego Grzegorza ze Słupi ok. 1375 roku.

Do wieku XII na Zachodzie Europy niemalże cała produkcja książki rękopiśmiennej była oparta na pracy skryptorium. Największy ich rozkwit przypadał na okres od X do XII wieku, natomiast od XIII stulecia skryptoria stopniowo zaczęły podupadać. W wiekach kolejnych, po wynalezieniu druku książka zaczęła się rozwijać. Jednakże dzięki klasztornym skryptoriom wiele dzieł myślicieli starożytności nie zostało zapomnianych.

\section{BIBLIOGRAFIA}

Bieńkowska B., Ksiażka na przestrzeni dziejów, Warszawa 2005.

Derwich M., Benedyktyński klasztor św. Krzyża na Łysej Górze w średniowieczu, Warszawa 1992.

Encyklopedia wiedzy o ksiażce, Wrocław 1971.

Gacki J., Benedyktyński klasztor na Łysej Górze, Kielce 2006.

Głombiowski K., Szwejkowska H., Ksiqżka rękopiśmienna i biblioteka w starożytności i średniowieczu, Warszawa 1983.

Grycz A., Gryczowa A., Historia ksiażki i bibliotek w zarysie, Warszawa 1972.

Kocowski B., Drzeworytowe ksiażki średniowiecza, Wrocław 1974.

Człowiek średniowiecza, red. J. Le Gof, Warszawa 2000.

Le Gof J., Kultura średniowiecznej Europy, Warszawa 1995.

Semkowicz W., Paleografia łacińska, Kraków 2007.

Świderkówna A., Ksiażka się rozwija, Wrocław 1970.

Żurowska K., Benedyktyni tynieccy w średniowieczu, Tyniec 1995. 


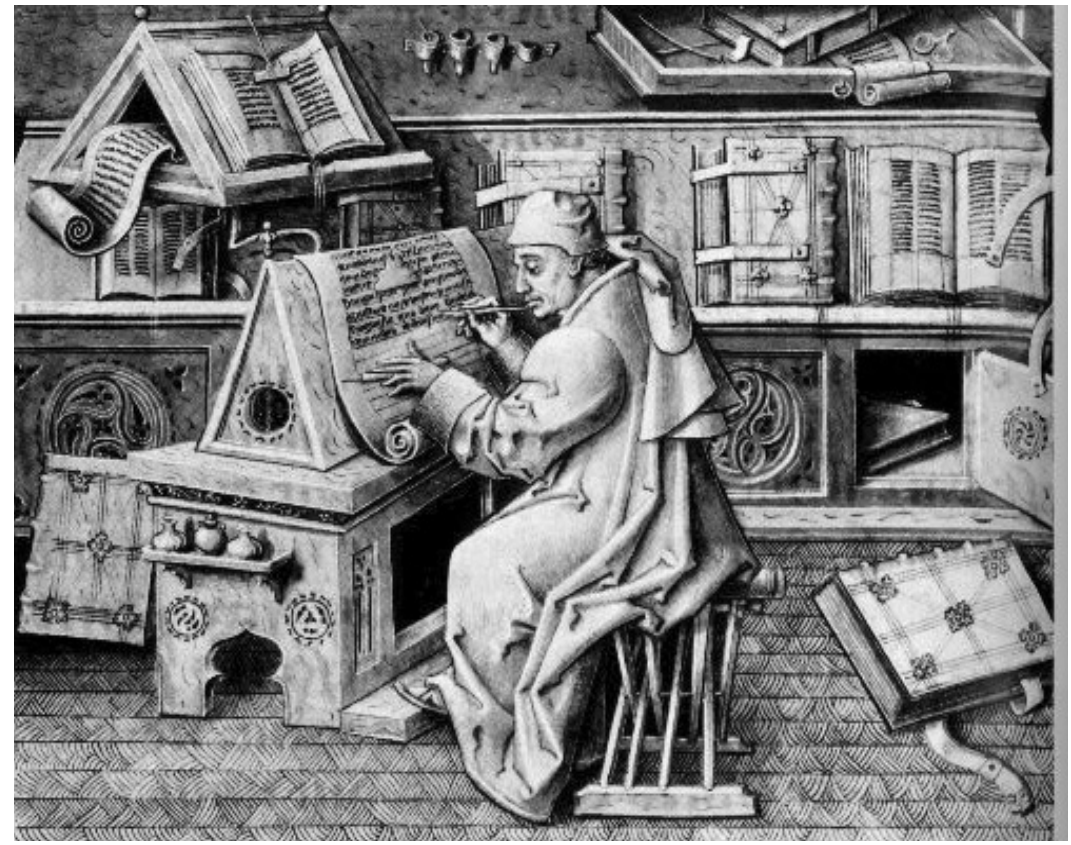

Wnętrze skryptorium średniowiecznego

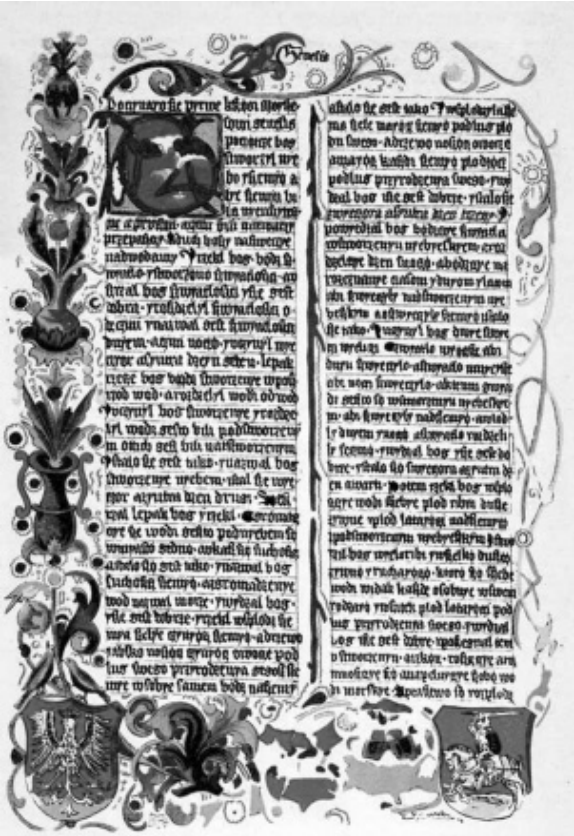

Biblia szaroszpatacka - pierwsza karta



Graduał tyniecki (XIV w.) - pierwsza karta 


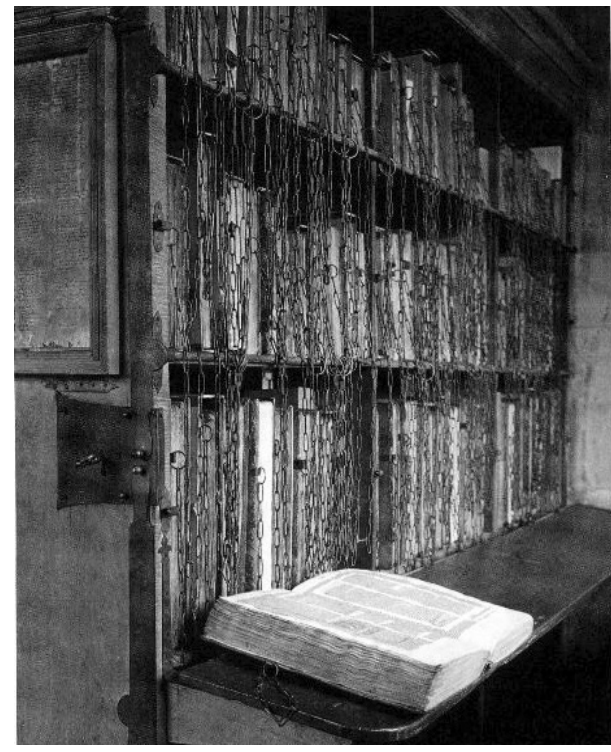

Księgi łańcuchowe

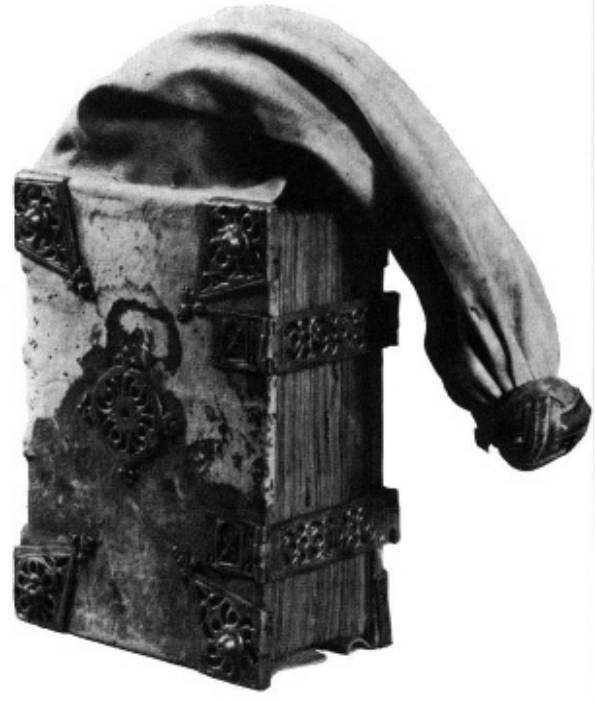

Oprawa sakwowa

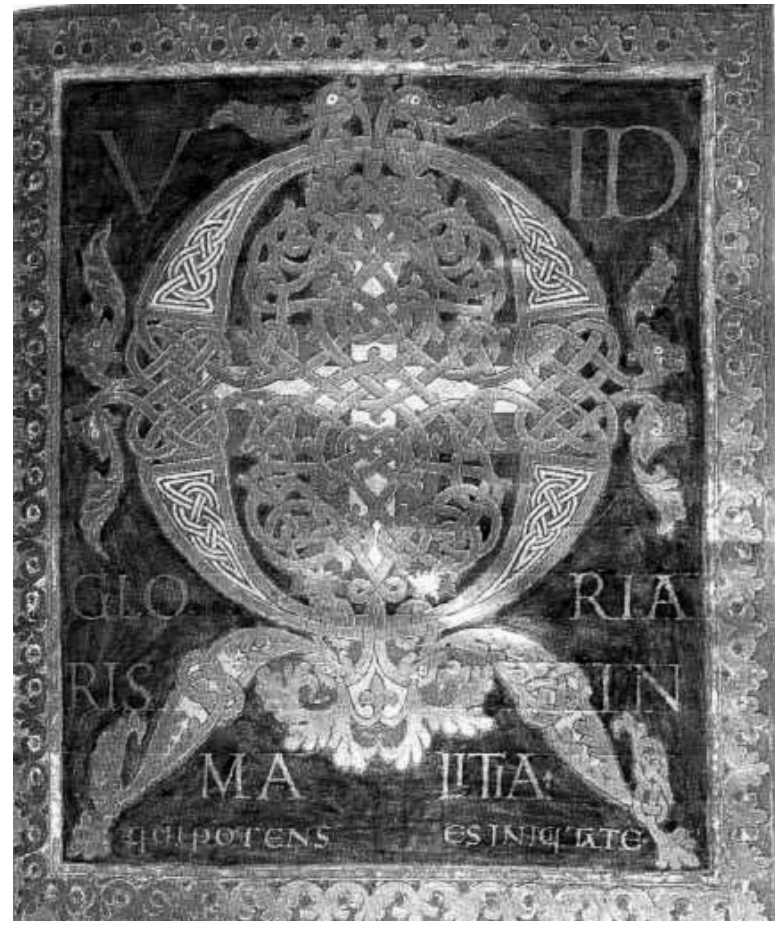

Psałterz Folcharta. Strona tytułowa. Inicjał $Q$. Biblioteka klasztorna w St. Gallen 